\title{
Частотно-контрастная характеристика ИК КРТ матриц в режиме работы с частично закрытыми пиксельными входными транзисторами
}

\author{
В.В. Васильев, А.В. Вишняков, Г.Ю. Сидоров, В.А. Стучинский \\ Институт физики полупроводников им. А.В. Ржанова, Новосибирск, \\ 630090, пр. Академика Лаврентьева, 13 \\ тел: +7 (383) 330-10-82, факс:+7 (383) 330-10-82, эл. почта: vishn@isp.nsc.ru
}

DOI 10.34077/RCSP2021-135

Диоды ИК фотоприемной матрицы управляются входными пиксельными транзисторами, которые определяют время накопления сигнала и рабочее напряжение на ИК фотодиодах. При обычных рабочих условиях сопротивление входного транзистора намного меньше сопротивления фотодиода и не лимитирует параметры работающего фотоприемного устройства. Входной пиксельный транзистор определяет нагрузочную кривую, вдоль которой изменяются ток и напряжение ИК-фотодиода при изменении входного фототока. Входные транзисторы открываются/закрываются изменением напряжения на затворе. В случае хорошо открытых транзисторов полное изменение тока равно изменению входного фототока. Для частично открытых транзисторов входной фототок частично компенсируется встречно направленным током прямосмещенного диода. Если пиксели матрицы не отделены друг от друга вытравленными меза- канавками, то этот компенсирующий ток растекается по соседним пикселям, одновременно с соседних пикселей притекают аналогичные токи, и в результате имеет место многократное переиспускание взаимно-наведенных токов. При этом, так как стекание в $p$ $n$ - переходы ограничено, фотоносители распространяются на большее расстояние от точки рождения, пространственное разрешение ухудшается, и величина ЧКХ уменьшается. Записав уравнение баланса токов с учетом взаимно-наведенных токов соседних пикселей, можно вычислить изменение ЧКХ при частичном закрытии пиксельных транзисторов. Можно показать, что влияние взаимно наведенных токов пикселей описывается дополнительным коэффициентом в ЧКХ, показанным на рисунке для различных напряжений на затворе пиксельных транзисторов, определяющих степень открытости этих транзисторов (полностью открытым транзисторам соответствует напряжение 0.9-1.1 В, при этом рассчитанный коэффициент равен единице). Полная измеряемая ЧКХ равна произведению ЧКХ объектива на ЧКХ матрицы с полностью открытыми транзисторами и на показанный на рисунке рассчитанный коэффициент. При сравнении с экспериментом измеренная ЧКХ матрицы с частично закрытыми транзисторами делилась на измеренную ЧКХ матрицы с полностью открытыми транзисторами. При этом ЧКХ объектива и матрицы с полностью открытыми транзисторами сокращаются, - и остается только показанный множитель. Сплошными линиями показан расчет, а точками - результат измерения на СВИК-КРТ матрице с пикселем размером 30х30 мкм. При закрывании транзисторов, вблизи частоты Найквиста (16.7 штр/мм) появляется провал в ЧКХ. Предельная величина этого провала при почти полном закрывании транзисторов определяется, согласно рассматриваемой модели, длиной диффузии неосновных носителей заряда в

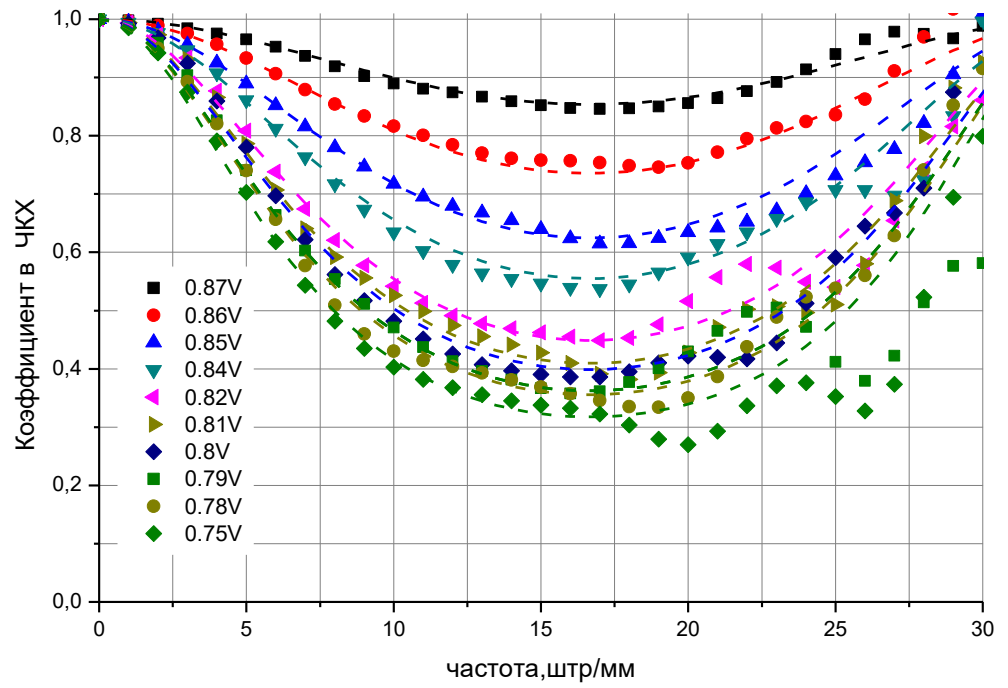

фоточувствительном слое матрицы. С ростом длины диффузии до бесконечности величина ЧКХ в минимуме для предельной кривой (для почти полностью закрытых транзисторов) уменьшается до нуля. Путём одновременного сравнения с экспериментом кривых ЧКХ и фотосигнала при однородной засветке, был определен коэффициент передачи тока между соседними пикселями, который хорошо согласуется с проведенными ранее расчетами методом Монте-Карло. 